\title{
Effects of Voluntary Apnea on Haemodynamic Responses during Groundwork Techniques of Judo
}

\section{Jean Georges André Moulongo ${ }^{1,2 *}$, Elvina Lys Surêche Massamba1, Alphonse Massamba ${ }^{1,3}$, Bernard Packa Tchissambou ${ }^{1}$}

${ }^{1}$ Effort Laboratory of Physiology, Biomechanics, Superior Institute of Physical Education, University Marien NGOUABI, Brazzaville, Congo

${ }^{2}$ Division of Research, Documentation and the Files, National Institute of Youth and Sports, Brazzaville, Congo

${ }^{3}$ Laboratory of Nutrition, Health and Human Motricity, Superior Institute of Physical Education, University Marien NGOUABI,

Brazzaville, Congo

Email: ^jgamoulongo@gmail.com

How to cite this paper: Moulongo, J.G.A., Massamba, E.L.S., Massamba, A. and Packa Tchissambou, B. (2016) Effects of Voluntary Apnea on Haemodynamic Responses during Groundwork Techniques of Judo. Worla Journal of Cardiovascular Diseases, 6, 300311.

http://dx.doi.org/10.4236/wjcd.2016.69034

Received: July 19, 2016

Accepted: September 18, 2016

Published: September 21, 2016

Copyright $\odot 2016$ by authors and Scientific Research Publishing Inc. This work is licensed under the Creative Commons Attribution International License (CC BY 4.0).

http://creativecommons.org/licenses/by/4.0/ (c) (i) Open Access

\begin{abstract}
Context: Several studies were conducted on physiology of apnea in scuba diving. No survey has been reported in fighting sports. Objective: To evaluate cardiovascular variations misled by voluntary apnea during groundwork techniques of judo training. Methods: The temporal evolution of heart rate and modifications of the blood pressure have been investigated during cross sectional and experimental study. A total of 28 Congolese judoists took part in the study. The voluntary apnea was achieved by a judoist to try to carry out two kinds of groundwork (hon-gesa-gatame and kami-shiho-gatame). According to the case, Student $t$ test and analysis of variance were used for comparing data. Multivariate analysis was used to evaluate the effect of "type of groundwork technique $\times$ category of weight". Results: Between 0 and 3 seconds, tachycardia has been observed during the static groundwork techniques and then bradycardia occurred to 3 - 9 seconds for the dynamic groundwork techniques : $+6.8 \%$ of the rest frequency versus $-9.4 \%$ for hon-gesa; $+4.9 \%$ versus $-13.7 \%$ for $k a-$ mi-shiho. Thereafter, it followed a fluctuation of heart rate of $9-15$ seconds. Beyond, a stagnation was noted for hon-gesa, whereas a minimal increase $(<5 \%)$ for $k$ ami-shiho. In relation to the systolic arterial pressure, a meaningful rise was recovered: $+46.5 \%$ (hon-gesa) versus $+50.1 \%$ (kami-shiho) in static exercise; $+43.4 \%$ (hon-gesa) versus $+43.3 \%$ (kami-shiho) in dynamic exercise. The report was similar for the diastolic arterial pressure: $+31.5 \%$ (hon-gesa) versus $30.0 \%$ (kami-shiho) in static exercise; $+20.3 \%$ (hon-gesa) versus $+23.8 \%$ (kami-shiho) in dynamic exercise. Conclusion: The apnea consecutive to the hindrance of an exit groundwork tech-
\end{abstract}


nique to judo drags bradycardia increased while exercise realized static posture, and a rise of the arterial pressure.

\section{Keywords}

Apnea, Heart Rate, Arterial Pressure, Groundwork Technique of Judo

\section{Introduction}

The apnea is defined like the temporary stop of the gaseous exchange between the lungs and the atmosphere [1]. It is neither a stop of breathing to the tissue direction of the term, nor a total stop of ventilation since when the apnea exceeds a few tens of seconds and the ventilatory movements begin again, even if they are ineffective because the glottis is closed [2]. The sports activity headlight where it is found is deep-sea diving [3] [4]. In practice of this one, the sportsman is subjected to problems involved in the hydrostatic pressure (risks of accidents barotraumatic and pathologies of decompression) and on the hypoxia [5]-[7]. On a par with hemodynamic parameters, these studies carried out the influence of an apnea at rest, during a static or dynamic effort, and raised variations in the evolution of the heart rate and the blood pressure. According to these authors, the cardiovascular modifications observed result from a vagale inhibitor and a sympathetic stimulation. Those are responsible for a tachycardia with secondary rise in the cardiac flow and the systolo-diastolic blood pressure [8] [9]. However, the review of literature does not give a report on a similar work concerning the judo. However, this Olympic discipline is made conspicuous by two types of gestural techniques: movements of projection (called "stroke waza") and movements on the ground ("katame waza") [10]. In this last group, one distinguishes the movements from strangulation and luxation of arm, as well as the fixed assets [10]. During the practice of these last, a partner maintains another judoist plated on the ground, without leaving itself there during 25 seconds to obtain the victory (ippon) by granting of 10 items [10]. With this intention, one of the strategies most used is to carry out an apnea in static and dynamic position at the time when the adversary maintained on the ground tries to break the plating [11]. The realization of this apnea involves a static or dynamic exercise of arms to which one can add the lower limbs [11].

Consequently, a good control of the partner during these fixed assets often requires auxotonic contractions at the level latero-costal or medio-sternal, carried out with respiratory humming. However, no data are available on haemodynamic responses of the cardiac answers to the apnea during forced assets of judo. Thus, the objective of this study is to evaluate the effects of a voluntary apnea on the cardiovascular variations during fixed assets carried out in static and dynamic postures in Congolese judoists.

The specific objectives are to analyze the kinetics of the heart rate (HR) according to the nature of immobilization and to determine the variations of the systolic blood pressure (SBP), diastolic blood pressure (DBP) and pulse pressure (PP). 


\section{Material and Methods}

\subsection{Topics}

The study, experimental and cross-sectional, was conducted in Brazzaville (Republic of Congo) during June 2016. On the whole, 34 judoists were preselected by the national trainer. All these subjects included from data heart rate (HR), electrocardiogram, echocardiogram, pulmonary radiography, respiratory (respiratory frequency) and ventilatory $\left(\mathrm{VO}_{2}, \mathrm{VCO}_{2}, \mathrm{VE}, \mathrm{VT}, \mathrm{VO}_{2} \max \right)$ and biochemical data (glycemia, lactatemia) were normal. However, the judokas included in the study answered the following criteria: 1) an age higher than 18 years; 2) a clinical, electrocardiographic and echographic picture normal; 3) a participation in the training of the national team of the seniors in the 5 days after the opinion of technical staff. In addition, information was collected on a register with identity of the judoist (sociodemographic characteristics), medical antecedents and its factors of cardiovascular risk (tobacco consumption, arterial hypertension, diabetes, status of cell sickle disease, alcohol and cooking salt consumption). Were excluded judoists carrying cell sickle disease AS or SC, judoists current smokers and regular alcohol consumers. At the end of this procedure, 28 judokas constituted the sample of the study. The mean age was $24.3 \pm 1.5$ years (range: $21-27$ years). They belonged to the seven categories of weight recommended by the International Federation of Judo (F.I.J.), at a rate of 4 judoists per category. These judoists, elite level, were trained on average 6 days per week, at a rate of 5 hours per day. They had begun the drive from judo one month before the experimentation. The morphological characteristics are presented in Table 1.

The socio-economic level of the judokas was evaluated by using the analysis of the multiple correspondences (AMC) with software XLSTAT Pro version 7.5 starting from the economic variables. The socio-economic level was definite high (level 1) for 5 judoists, mean (level 2) for 17 judoists and low (level 3) for 6 judoists. The educational level concerned the secondary cycle for 24 judoists and the university cycle for 4 judoists. Compared to the profession, 19 judoists were students, 6 workers of liberal sector and 3 servant civils.

\subsection{Methods}

Experimental work had comprised two meetings, divided into two days. The being practiced judo with two (sport duel), lasting the first meeting, each judoka carried out two fixed assets (plating on the ground of the other partner): hon-gesa-gatame and kami-shiho-gatame in statics, with and without respiratory blocking. During the second

Table 1. Anthropometric characteristics of the subjects.

\begin{tabular}{lcc}
\hline & Whole group $(\mathrm{N}=28)$ & Range \\
\hline Height $(\mathrm{cm})$ & $169.5 \pm 5.4$ & $171-183$ \\
Weight $(\mathrm{kg})$ & $76.4 \pm 13.2$ & $59.6-117.2$ \\
BMI $\left(\mathrm{kg} / \mathrm{m}^{2}\right)$ & $26.3 \pm 0.5$ & $25.2-33.1$ \\
\hline
\end{tabular}

BMI: body mass index. 
meeting, the same judoka carried out these two gestural in dynamics, according to the two above mentioned methods. Hon-gesa-gatame is a control latero-costal technique (Figure 1), whereas the second relates to the sternum part of thorax (Figure 2).

The exercises were carried out after muscular heating from 10 to 15 minutes, which made it possible to raise the heart rate in the range of 120 - 130 beats per minute (b/min). Respiratory blocking was carried out by that which carried out the immobilization (Tori in judo language), after a major inspiration. The respiratory stop was maintained longest possible during the immobilization. As soon as the subject took again its breathing, it stopped the exercise.

During each immobilization, the HR and the blood pressure [systolic blood pressure (SBP) and diastolic blood pressure (DBP)] were measured at Tori with $\mathrm{t}=0,15,19$ and 24 seconds (time corresponding to quotations of the fixed assets in the regulation of the International Judo Federation (I.J.F.) [12], using a cardioscope Baumann Recorder BHL 5000 , with recording uninterrupted data. The sensor was firmly fixed using a cross-belt and adhesive bands, under the kimono (judogi), on the level of the left hypochondriac, without manifest gene for the two judoists. Slept on the back, the partner who underwent the movement reacted in a regular way to the technique (tentative of exit of immobilization), to $50 \%$ of the voluntary maximum force (FMV). In the event of successful exit, the experiment was stopped at once.

Between each exercise, the return of the parameters recorded to their initial value at

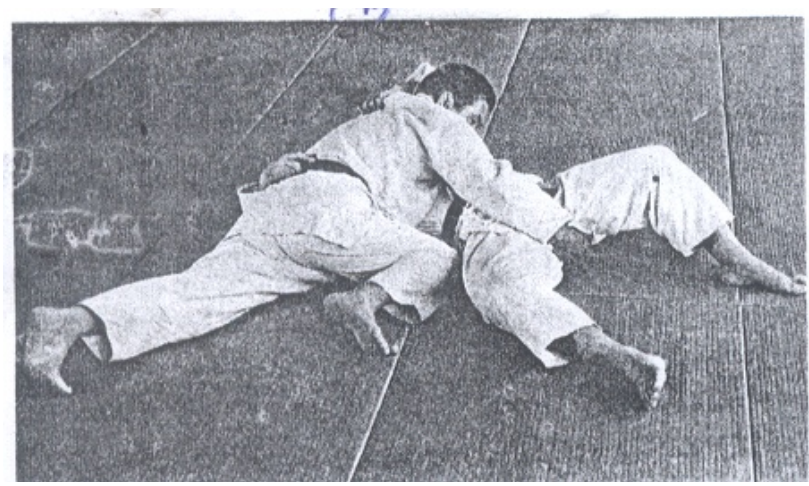

Figure 1. Hon-gesa-gatame.

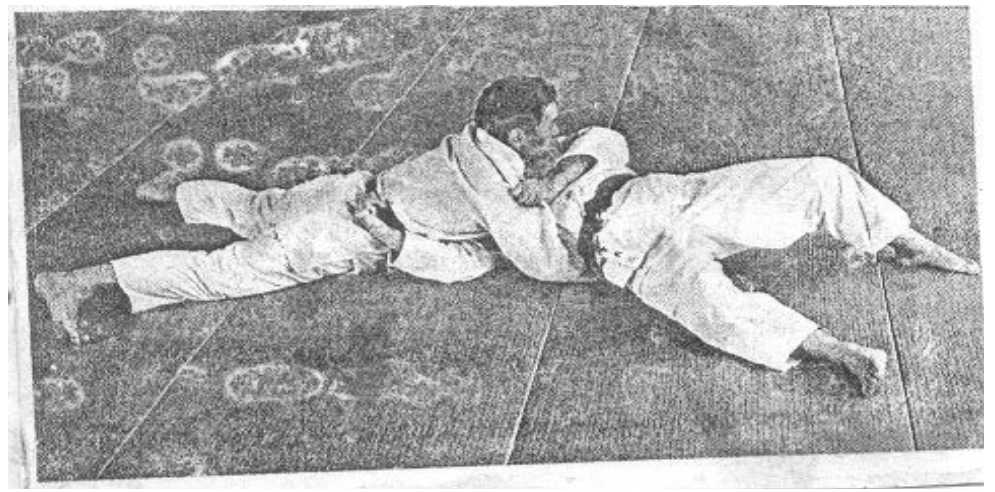

Figure 2. Kami-shiho-gatame. 
the end of 10 minutes constituted an essential condition. The composition of two judoists during the fixed assets took account of the weight categories, and the principle of stability of the binomials was retained.

Three variables were studied: $\mathrm{HR}, \mathrm{SBP}, \mathrm{DBP}$ and pulse pressure $\left(\mathrm{PP}^{0}\right)$. They were given during the apnea carried out during the execution of hon-gesa-gatame and kami-shiho-gatame in dynamic posture versus static posture. The weight category of the judoists having taken part in the experimentation constituted the independent variable. The other independent variable was summarized with the taking into account of the time carried out during the apnea.

\subsection{Statistical Analysis}

Because of the low number of subjects, the test of Kolmogoroff-Smirnoff was carried out in order to be ensured of the normality of the distribution of each variable. The various quantitative data were expressed by their mean accompanied by standard deviation. The test $t$ of Student used to compare the evolution of each hemodynamic parameter according to the nature of the immobilization. In order to study the temporal variations of $\mathrm{HR}$ and blood pressure according to the type of effort, an analysis of variance (ANOVA) to a way in total randomization, were carried out. The ANOVA was supplemented by the test of Newman-Keuls to appreciate the level of difference. In addition, a multivariate variance analysis (MANOVA) to 2 factors (type of immobilization $\mathrm{X}$ weight category) was also used for determining the mean of the scores of each of the 4 following decisions: koka (14 seconds), yuko (19 seconds), waza-ari (24 seconds) and ippon (25 seconds). All statistical analyses were performed with Mathcad, version12.0, at the department of statistics of Brazzaville Faculty of Sciences. p-value $\leq$ defined statistical significance.

\section{Results}

The temporal evolution of the mean values of HR (Tables 2-4), during the static and dynamic fixed assets, revealed: 1) a tachycardia for the static fixed assets (IS) from 0 to 3 seconds, followed by a bradycardia for the static exercises (ISA) and dynamic (IDA) carried out between 3 and 9 seconds; 2) a regular increase in the heart rate at the time of the efforts static from 9 to 12 seconds, and dynamic from 5 to 12 seconds); 3) a significant increase in the heart rate during 15 and 19 seconds for the fixed assets carried out in statics followed by a significant bradycardia $(p<0.01)$ for the fixed assets carried

Table 2. Basal cardiovascular values.

\begin{tabular}{ccc}
\hline & Whole group $(\mathbf{N}=28)$ & Range \\
\hline HR (b/min) & $64.5 \pm 2.0$ & $58-66$ \\
SBP (mmHg) & $121.3 \pm 0.8$ & $118-124$ \\
DBP (mmHg) & $88.1 \pm 0.2$ & $86-90$ \\
PP $^{0}(\mathrm{mmHg})$ & $33.2 \pm 0.5$ & $31.4-35.0$ \\
\hline
\end{tabular}

HR: Heart Rate; SBP: Systolic Blood Pressure; DBP: Diastolic Blood Pressure; PP ${ }^{0}$ : Pulse Pressure. 
Table 3. Variations of the blood pressure according to the immobilization for whole group.

\begin{tabular}{cccccc}
\hline & ISA & IDA & IS & ID & p-value \\
\hline HR (b/min) & $94.5 \pm 2.0$ & $96.7 \pm 0.8$ & $117.2 \pm 1.4$ & $98.4 \pm 1.6$ & 0.12 \\
SBP (mmHg) & & & & & \\
Hon-gesa & $177.7 \pm 2.1^{* * *}$ & $173.8 \pm 1.2$ & $171.5 \pm 1.8$ & $147.6 \pm 1.5$ & 0.01 \\
Kami-shiho & $183.1 \pm 1.3^{* * *}$ & $180.3 \pm 1.3$ & $180.0 \pm 1.9$ & $150.3 \pm 1.2$ & 0.01 \\
DBP (mmHg) & & & & & \\
Hon-gesa & $115.9 \pm 9.8^{* * *}$ & $106.0 \pm 10.4$ & $109.0 \pm 11.2$ & $71.2 \pm 8.8$ & 0.04 \\
Kami-shiho & $114.4 \pm 1.7^{* * *}$ & $109.1 \pm 10.0$ & $110.5 \pm 8.1$ & $72.1 \pm 9.6$ & 0.01 \\
\hline
\end{tabular}

SBP: Systolic Blood Pressure; DBP: Diastolic Blood Pressure; ISA: Static Effort in Apnea; IDA: Dynamic Stress in Apnea; IS: Static Effort with Free Breathing; ID: Dynamic Stress with Free Breathing; ${ }^{* * *}$ : Difference highly significant.

out in dynamics (ID), a time ranging between 19 and 25 seconds. However, the decrease of HR expressed as a percentage of the cardiac basal frequency proved faster for the dynamic exercises carried out in apnea. This one characterized the nature of the effort.

The SBP (Table 3) reached average values significantly higher during the static fixed assets with apnea $(\mathrm{p}<0.01)$, and of the dynamic fixed assets with apnea $(\mathrm{p}<0.05)$, compared with those raised at the time of the dynamic stresses with free breathing. Differences of about $16.9 \%$ observed for the immobilization "hon-gesa" and of $18.2 \%$ for "kami-shiho", were significant $(\mathrm{p}<0.05)$. The rise in the SBP noted in the event of respiratory stop, during the fixed assets carried out in dynamics, was also significant: +26 mmHg for "hon-gesa" ( $\mathrm{p}<0.05)$ and $+30 \mathrm{mmHg}$ for "kami-shiho" $(\mathrm{p}<0.01)$. The respiratory blocking carried out during the static effort was followed of a nonsignificant increase in the SBP (+6.2 mmHg for "hon-gesa" and $+3.30 \mathrm{mmHg}$ for "kami-shiho"). In addition, in the two types of static effort versus dynamic of the very high individual values of the SBP was recorded: $200 \mathrm{mmHg}$ for a subject in "hon-gesa", $210 \mathrm{mmHg}$ for a subject in "kami-shiho".

The mean values of DBP (Table 3) proved also higher in the event of fixed assets carried out in statics (with and without apnea) that during the dynamic fixed assets with free breathing. The average increasing rates of $+2.80 \mathrm{mmHg}$ for "hon-gesa" and $+4.90 \mathrm{mmHg}$ for "kami-shiho", linked to apnea during the static efforts, were not significant. In the fixed assets carried out in dynamics and with apnea, of significant rises in the diastolic blood pressure, respectively in $+34.8 \mathrm{mmHg}$ for "hon-gesa" ( $\mathrm{p}<0.05)$ and $+37.0 \mathrm{mmHg}$ for "kami-shiho" ( $\mathrm{p}<0.01)$, were raised. Those remained however lower than the variations established during the fixed assets in statics $(-38.5 \mathrm{mmHg}$ for "hon-gesa" and $-44.4 \mathrm{mmHg}$ for "kami-shiho") and especially than those of the dynamic stresses with apnea $(-41.3 \mathrm{mmHg}$ for "hon-gesa" and $-49 \mathrm{mmHg}$ for "kamishiho').

Lastly, the MANOVA revealed a multivariate principal effect of the weight category of the judoist for the HR (Wilk's lambda $=0.77, \mathrm{~F}(6,21)=10.722, \mathrm{p}<0.001$ ) and for 
the type of immobilization (Wilk's lambda $=0.57, \mathrm{~F}(6,21)=4.251, \mathrm{p}<0.01$ ), as well as an interaction between the two independent variables (Wilk's lambda $=0.82, F(6,21)=$ 3.04, $\mathrm{p}<0.05)($ Table 4).

\section{Discussion}

The principal results of this study are as follows. Firstly, the realization of a voluntary apnea in order to prevent an attempt at exit of immobilization to the judo involves a bradycardia at Tori (judoka carrying out the catch); this one starts as of the 32nd second and reached its maximum at the 19 seconds. Thereafter, it remains quasi-stable and can even decrease to the 24 seconds because of the respiratory jolts with glottis closed at the time of the last phase of maintenance of the adversary. Secondly, the SBP and DBP increase gradually during the apnea (up to $20 \%$ of their initial value) to be stabilized during the five last seconds. Thirdly, the bradycardia and the arterial pressure decrease are more marked in the dynamic fixed assets compared to statics. However, this study comprises weakness to extrapolate these results on the whole of the fixed assets of judo. It acts in particular: relatively small size of the sample of the judokas, their level of competition at the international level, absence of temporal statements of the apnea and gasometric data. Another weakness owing to the fact that the two fixed assets are not used in competition. Thus, these observations don't deteriorate the reliability of our results. The later studies should integrate all these parameters, as well as a long-term follow-up of the whole of the high level Congolese judoists are to be planned to refine these preliminary data.

\subsection{Heart Rate}

In our series, the basal HR varied from 54 to $73 \mathrm{bpm}$, with an average of $61.2 \pm 1.5$ bpm. This moderate bradycardia could be allotted partly to vagale hypertonicity as can develop it the judo. This one is related to the action of the two pneumogastric ones, the right acting preferentially on the node of Keith and Flack, it left on the node of Tawara. The theory of Reindell [12], making increase in volume of the heart the cause of the deceleration of the rate of heartbeat, cannot thus be retained, because the bradycardia precedes hypertrophy.

Under the conditions of respiratory blocking during fixed assets, after a light increase in the HR, during the 3 first second, the evolution is identical, some is the type of immobilization and their procedure (static versus dynamic); however, all the variations observed from 3 to 9 seconds between "hon-gesa" and "kami-shiho" are not significant. The reduction in the HR during the apnea is clearer from the 9 second in the immobilization "hon gesa" than in "kami-shiho". Sanchez and Sebert [13] established the same report during the respiratory stop at the time of static efforts of $30 \%$ and $40 \%$ of the FMV at the men. As Heyters and Dandoy [14], we observed a tiny bradycardia during last seconds of the apnea. The explanation of this bradycardia is plural multifactorielle. It can initially be allotted to an increase in the vagale activity, consequence of respiratory blocking; it also attached to the sympathetic nerve activity, itself induced by the 
Table 4. Variations of heart rate according to time range recording.

\begin{tabular}{|c|c|c|c|c|c|}
\hline & ISA & IDA & IS & ID & p-value \\
\hline $1^{\text {st }}$ category $(-60 \mathrm{~kg})$ & $\mathrm{N}=4$ & $\mathrm{~N}=4$ & $\mathrm{~N}=4$ & $\mathrm{~N}=4$ & \\
\hline $0-5 s$ & $75.1 \pm 0.3$ & $62.1 \pm 3.1$ & $71.3 \pm 1.2$ & $73.1 \pm 0.5$ & 0.03 \\
\hline $5-10 s$ & $91.0 \pm 0.2$ & $68.2 \pm 0.3$ & $83.5 \pm 0.8$ & $95.3 \pm 0.2$ & 0.04 \\
\hline $10-15 s$ & $96.3 \pm 0.4$ & $71.2 \pm 0.1$ & $125.2 \pm 0.2$ & $98.3 \pm 1.2$ & 0.02 \\
\hline $15-20 s$ & $92.8 \pm 0.3$ & $66.7 \pm 0.3$ & $111.6 \pm 0.5$ & $82.1 \pm 0.8$ & 0.01 \\
\hline $20-25 s$ & $90.1 \pm 0.4$ & $63.2 \pm 0.5$ & $108.2 \pm 0.2$ & $80.3 \pm 0.3$ & 0.02 \\
\hline $2^{\text {nd }}$ category $(-66 \mathrm{~kg})$ & $\mathrm{N}=4$ & $\mathrm{~N}=4$ & $\mathrm{~N}=4$ & $\mathrm{~N}=4$ & \\
\hline $0-5 \mathrm{~s}$ & $72.0 \pm 0.5$ & $60.4 \pm 0.3$ & $64.2 \pm 0.5$ & $69.4 \pm 0.3$ & 0.02 \\
\hline $5-10 s$ & $89.6 \pm 0.4$ & $65.1 \pm 0.5$ & $76.8 \pm 0.3$ & $69.4 \pm 0.3$ & 0.03 \\
\hline $10-15 s$ & $93.2 \pm 0.4$ & $70.3 \pm 0.2$ & $106.4 \pm 0.4$ & $93.1 \pm 0.2$ & 0.02 \\
\hline $15-20 s$ & $91.3 \pm 0.7$ & $68.1 \pm 0.4$ & $101.2 \pm 0.6$ & $90.4 \pm 0.5$ & 0.01 \\
\hline $20-25 s$ & $88.6 \pm 0.4$ & $65.4 \pm 0.5$ & $96.7 \pm 1.3$ & $86.1 \pm 0.2$ & 0.02 \\
\hline $3^{\text {rd }}$ category $(-73 \mathrm{~kg})$ & $\mathrm{N}=4$ & $\mathrm{~N}=4$ & $\mathrm{~N}=4$ & $\mathrm{~N}=4$ & \\
\hline $0-5 s$ & $73.1 \pm 0.3$ & $62.3 \pm 0.5$ & $63.7 \pm 0.3$ & $66.1 \pm 0.3$ & 0.04 \\
\hline $5-10 s$ & $85.4 \pm 0.6$ & $64.1 \pm 0.3$ & $68.2 \pm 0.5$ & $85.3 \pm 0.7$ & 0.04 \\
\hline $10-15 s$ & $91.2 \pm 0.4$ & $69.3 \pm 1.2$ & $79.1 \pm 0.4$ & $96.4 \pm 0.5$ & 0.03 \\
\hline $15-20 s$ & $87.6 \pm 0.3$ & $66.5 \pm 0.4$ & $75.3 \pm 0.2$ & $92.1 \pm 0.3$ & 0.04 \\
\hline $20-25 s$ & $85.2 \pm 0.5$ & $63.2 \pm 0.3$ & $72.6 \pm 0.6$ & $88.7 \pm 0.4$ & 0.03 \\
\hline $4^{\text {th }}$ category $(-81 \mathrm{~kg})$ & $\mathrm{N}=4$ & $\mathrm{~N}=4$ & $\mathrm{~N}=4$ & $\mathrm{~N}=4$ & \\
\hline $0-5 s$ & $70.4 \pm 0.5$ & $68.3 \pm 0.3$ & $65.4 \pm 0.6$ & $67.1 \pm 0.3$ & 0.05 \\
\hline $5-10 s$ & $76.1 \pm 0.3$ & $65.1 \pm 0.1$ & $71.2 \pm 0.3$ & $72.1 \pm 0.2$ & 0.05 \\
\hline $10-15 s$ & $85.6 \pm 0.2$ & $72.3 \pm 0.4$ & $79.6 \pm 0.5$ & $78.4 \pm 0.4$ & 0.03 \\
\hline $15-20 s$ & $80.2 \pm 0.4$ & $68.2 \pm 0.2$ & $73.2 \pm 0.2$ & $71.2 \pm 1.1$ & 0.04 \\
\hline $20-25 s$ & $76.3 \pm 0.6$ & $64.5 \pm 0.3$ & $69.1 \pm 0.4$ & $68.3 \pm 0.3$ & 0.03 \\
\hline $5^{\text {th }}$ category $(-90 \mathrm{~kg})$ & $\mathrm{N}=4$ & $\mathrm{~N}=4$ & $\mathrm{~N}=4$ & $\mathrm{~N}=4$ & \\
\hline $0-5 s$ & $72.1 \pm 0.3$ & $70.4 \pm 0.5$ & $67.2 \pm 0.3$ & $69.2 \pm 0.5$ & 0.05 \\
\hline $5-10 s$ & $77.5 \pm 0.6$ & $75.2 \pm 0.3$ & $73.4 \pm 0.5$ & $72.5 \pm 0.3$ & 0.04 \\
\hline $10-15 s$ & $87.1 \pm 0.4$ & $81.6 \pm 0.4$ & $76.0 \pm 0.7$ & $79.1 \pm 0.4$ & 0.04 \\
\hline $15-20 s$ & $82.3 \pm 0.5$ & $72.3 \pm 0.5$ & $71.3 \pm 0.4$ & $70.6 \pm 0.3$ & 0.03 \\
\hline $20-25 s$ & $80.1 \pm 0.4$ & $69.1 \pm 0.3$ & $68.2 \pm 0.2$ & $68.2 \pm 0.3$ & 0.02 \\
\hline $6^{\text {th }}$ category $(-100 \mathrm{~kg})$ & $\mathrm{N}=4$ & $\mathrm{~N}=4$ & $\mathrm{~N}=4$ & $\mathrm{~N}=4$ & \\
\hline $0-5 \mathrm{~s}$ & $74.2 \pm 0.6$ & $72.8 \pm 0.4$ & $73.4 \pm 0.5$ & $71.3 \pm 0.5$ & 0.06 \\
\hline $5-10 s$ & $78.5 \pm 0.3$ & $76.4 \pm 0.2$ & $78.1 \pm 0.3$ & $77.6 \pm 0.3$ & 0.08 \\
\hline $10-15 s$ & $86.2 \pm 0.4$ & $84.3 \pm 0.5$ & $85.6 \pm 0.2$ & $86.7 \pm 0.6$ & 0.07 \\
\hline $15-20 s$ & $81.0 \pm 0.5$ & $80.1 \pm 0.3$ & $80.1 \pm 0.4$ & $80.5 \pm 0.4$ & 0.10 \\
\hline
\end{tabular}




\begin{tabular}{cccccc} 
Continued \\
\hline $20-25 \mathrm{~s}$ & $79.1 \pm 0.4$ & $78.3 \pm 0.2$ & $76.4 \pm 0.3$ & $72.3 \pm 0.2$ & 0.05 \\
$7^{\text {th }}$ category $(+100 \mathrm{~kg})$ & $\mathrm{N}=4$ & $\mathrm{~N}=4$ & $\mathrm{~N}=4$ & $\mathrm{~N}=4$ & \\
$0-5 \mathrm{~s}$ & $72.3 \pm 0.5$ & $73.1 \pm 0.3$ & $71.3 \pm 0.2$ & $69.3 \pm 0.3$ & 0.08 \\
$\mathbf{5}-10 \mathrm{~s}$ & $76.1 \pm 0.2$ & $78.3 \pm 0.4$ & $77.5 \pm 0.3$ & $74.1 \pm 0.5$ & 0.07 \\
$10-15 \mathrm{~s}$ & $84.3 \pm 0.4$ & $85.1 \pm 0.2$ & $86.2 \pm 0.5$ & $81.3 \pm 0.2$ & 0.06 \\
$15-20 \mathrm{~s}$ & $80.1 \pm 0.3$ & $81.4 \pm 0.3$ & $82.3 \pm 0.3$ & $75.6 \pm 0.3$ & 0.05 \\
$20-25 \mathrm{~s}$ & $76.5 \pm 0.6$ & $76.3 \pm 0.2$ & $79.1 \pm 0.2$ & $71.2 \pm 0.4$ & 0.07 \\
\hline
\end{tabular}

ISA: Static Effort in Apnea; IDA: Dynamic Stress in Apnea; IS: Static Effort with Free Breathing; ID: Dynamic Stress with Free Breathing.

isometric constraints. In addition, even if the gasometric data are not objectified, it is known that the alveolar pressure of oxygen $\left(\mathrm{C}_{\mathrm{a}-\mathrm{v}} \mathrm{O}_{2}\right.$ decreases so as to little close linear according to the time of apnea). Thus, as the reserves of $\mathrm{O}_{2}$ are reduced, the exchanges slow down because the gradient of pressure between cell and blood $\left(\mathrm{PaO}_{2}\right.$ decreases [3]). Concomitantly, the alveolar carbon dioxide pressure grows quickly in the 10 first second of apnea, then more and more slowly for tending towards an asymptote bordering 55 to $60 \mathrm{mmHg}$. This kinetics results from the intervention of the substances plugs present in the ambient conditions; they fix most of $\mathrm{CO}_{2}$ product or being able to be evacuated by the pulmonary way during the apnea [15]. In addition, the arterial $\mathrm{pH}$ decrease regularly during the apnea, any cause increasing the metabolisms by accelerating the increase in the $\mathrm{PaCO}_{2}$ the fall of the $\mathrm{C}_{\mathrm{A}-\mathrm{v}} \mathrm{O}_{2}$ and the $\mathrm{pH}$ [16]. Lastly, the intensity relatively higher of the static effort in "kami-shiho" (58\%) of the basal HR of the maximum effort versus $56 \%$ in "hon-gesa" would explain the importance of the bradycardia noted for the first type of immobilization, modulated by the parasympathetic nervous system [3] [17].

\subsection{Blood Pressure}

The distribution of the basal blood pressures didn't concern hemodynamic anomaly at our subjects. The differences in variations of the SBP and DBP in our study would be explained by the theory of Sarnoff and Michel [18]. Indeed, according to this one, the cardiac response to the effort represents the integration of the effects of tachycardia, stimulation sympathetic nerve and the mechanism of Franck-Starling, itself related to the increase in the venous return. And, if one explains the relation $\mathrm{Pa}=\mathrm{Q} \times \mathrm{R}$, where $\mathrm{Q}$ indicates the cardiac flow and $\mathrm{R}$ peripheral resistances, in the fixed assets carried out into dynamic the increase in the heart rate, as that of the venous return is the resultant of the action of breathing and of the effect pumps muscles, alternatively in activity and relaxation. The volume of ejection proves in this case more significant and the higher flow, thus generating a rise in the SBP.

As for the weak variations of the DBP observed in statics at our subjects, they can be connected to the reduction in peripheral resistances. Indeed, in this type of immobilization, the action pumps muscles with work is not very intense, from where a less rise in 
the venous return [19]-[21]. This effect results in a weak acceleration of HR, and there is no significant mobilization of the flow. Consequently, peripheral resistances increase because of the constant contraction of the muscles, especially when the intensity of this one is higher than $15 \%$ of the FMV [22].

The systolic blood pressures and diastolic reach a raised level thus, following the simultaneous increase in $\mathrm{Q}$ and $\mathrm{R}$. during the apnea carried out during a muscular exercise, the hyper thoracic pressure is also likely to raise the resistance of the pulmonary network and to decrease the venous return. Consequently, the increase in the vagale activity which appears at this time would involve the bradycardia and a reduction in the flow.

\subsection{Influence Specificity of the Apnea and Posture on the Blood Pressure}

Respiratory blocking intervening with the judo comprises several characteristics. Thus, when it is carried out in respiratory position, blocking obeys the principle of "the haragei" (control of abdominal energy). This principle rises from the biomechanical concept which breaks up the human body into two biokinetic chains: that consisted the basin and the lower limbs [10]. The coordination of these chains via the abdomen conditions the control of the immobilization. One of the roles of the abdomen would consist in transforming the accumulated muscular deformation energy itself related to the components into series of the first chain of two specific energies: one of abdominal, potential and elastic contraction, the other of muscular deformation of the second chain. The following diagram schematizes these transformations.

$$
\begin{aligned}
\left.\mathrm{U}_{1} \mathrm{U}_{2} \stackrel{\text { Pelvist leg }}{\longrightarrow}_{\text {Trunk }} \underset{\text { Arm+abdomen }}{\longrightarrow} \mathrm{W}\left(\mathrm{k}_{1}\right)=1 / 2 \mathrm{kx}^{2}\right) \longrightarrow
\end{aligned}
$$

$W\left(k_{i}\right)$, work carried out by the forces of muscular contraction is equal to $2 \mathrm{l}_{\mathrm{i}} \mathrm{F}_{\mathrm{oi}} / \mathrm{n}_{\mathrm{i}} \mathrm{s}_{\mathrm{i}} ; U_{i}$ is the potential energy of deformation of the caused biokinetic chains.

According to Sacripanti [10], Foi is the maximum tetanico-isometric force of the involved members (i), $N_{i}$ the voluminal density of the bridges of myosin relating to it, $S_{i}$ the length of the sarcomeres and Li the density between the zones.

To obtain a maximum contraction of the upper limbs, the transfer of abdominal energy should be optimal. In this case, the abdominal contraction and thoracic blocking induce a lowering of the diaphragmatic zone, which compresses the internal organs and raises the centripetal pressure of the abdominal fluid. In addition, the morphometric studies undertaken by Mead and Loring [23] showed a positive correlation between the mass and the thickness of the muscular part of the diaphragm on the one hand, and the body mass of the other; the values they are also increased at the subjects with intense physical activity. Thus during thoraco-abdominal blocking, the diaphragmatic geometry, joined to the synergistic action of the additional breathing and abdominal muscles, seem to contribute to the rise in the blood pressures.

Moreover, the position and the force exerted by the upper and inferior limbs that 
play, in practice on the ground, a paramount role in control and the blocking of the partner [24] contribute to vary the blood pressures in the event of dynamic immobilization compared to static immobilization. Indeed, when the muscular exercise is dynamic, peripheral resistances are decreased compared to the static exercise where they are increased [25]. These variations are reflected on the systolic volume of ejection and the blood flow. Moreover, it is known that the intensity of the muscular contractions subordinates the local blood flow [24]. Lastly, the differences in posture at Tori in the fixed assets "hon gesa" and "kami-shiho" can explain the variations of the pressures noted between the two techniques [25].

\section{Conclusion}

The practice of the apnea during fixed assets of judo has an influence on the cardiovascular adaptations of the organization. The absolute values of the HR and the SBP and DBP indicate that the dynamic stress with free breathing is the least constraining for the cardio-circulatory system. The respiratory stop during the fixed assets carried out in statics, at $60 \%$ of the maximum effort, puts in difficulty the cardiovascular apparatus by a strong increase in the SBP and a reduction in the HR. Lastly, the hemodynamic behavior of the upper limb in contraction differs according to the group from immobilization and the intensity from "the handgrip".

\section{Author Contributions}

MJGA designed the study, participated in the implementation of experimental procedure and wrote the first version of the article. MELS was involved in the acquisition of field data. MA as validated the experimental procedure, performed the statistical analysis of data and reread the final version of the article.

\section{References}

[1] West, J.B. (2003) La physiologie respiratoire. $6^{\mathrm{e}}$ éDition, Maloine, Paris, 221 p.

[2] Launois-Rollinat, S. (2012) Physiologie du système respiratoire. Mis en ligne en janvier 206 sur le site. http://www-sante-ujf-grenoble.fr/SANTE/alpesmed/physiorespi/

[3] Corriol, J.H. (2002) La plongée en apnée: physiologie et médicine. $3^{\text {e }}$ Edition, Masson, Paris, $163 \mathrm{p}$.

[4] Delapille, P., Verin, E. and Tourny-Chollet, C. (2002) Réponses ventilatoires chez les apnéistes: Adaptations provoquées par un entraînement spécifique à l'apnée. Revue des Maladies Respiratoires, 19, 217-228.

[5] Norfleet, W. and Bradley, C. (2007) Can Eucapnic Voluntary Hyperventilation Prolong a Subsequent Breath-Hold? Undersea Biomedical Research, 34, 315-321.

[6] Chapuis, C. (2000) Données actuelles sur les mécanismes de rupture de l'apnée. Bull Med Subhyp, 19, 45-52.

[7] Lemaître, F. (2009) L'apnée: De la théorie à la pratique. APRAAS, Nice, 208 p.

[8] Bjertnaes, L., Hauge, A., Kjekshus, J. and Soylan, E. (2004) Cardiovascular Responses to Face Immersion and Apnea during a Steady State Muscle Exercise: A Heart Catherization Study on Human. Acta Physiol Scand, 140, 605-612 
[9] Findley, L.J., Farkas, G.A. and Rochester, D.F. (1995) Changes in Heart Rate during Breathing Interrupted by Recurrent Apnea in Human. Journal of Applied Physiology, 59, 536-542.

[10] Sacripanti, A. (1989) Biomeccanica del judo. Ed. Méditerranee, Roma, 205 p.

[11] Dreezen, E., Zicot, M.O. and Thys, H. (2006) Hétérogénéité des réponses hémodynamiques des membres inactifs lors des contractions isométriques de différentes intensités. J Biophys Biomec, 20, 96-97.

[12] Reindell, H. (2000) Herzbreislauffrankheiten und sport. Johann Ambrius, München, 207 p.

[13] Sanchez, J. and Sebert, P.M. (2005) A Comparison of Cardiac Responses in Dynamic and Isometric Exercise. European Journal of Applied Physiology, 66, 421-444.

[14] Heyters, C. and Dandoy, O. (1998) Influence du blocage respiratoire sur la fréquence cardiaque et les pressions artérielles mesurées pendant l'exercice dynamique et statique. Med Sport, 52, 384-389.

[15] Perrault, H. and Richard, R. (2012) Adaptation du transport circulatoire à l'exercice. Revue des Maladies Respiratoires, 29, 501-520. http://dx.doi.org/10.1016/j.rmr.2012.02.004

[16] Dematteo, A. (2006) La Syncope Hypoxique en Apnée Sportive: Description, Facteurs Favorisants.

[17] US National Heart, Lung and Blood Institute (2006) Report of the Task Force on Heart Rate and Blood Pressure in Athletes. Computers in Cardiology, 33, 473-479.

[18] Costill, D.L., Willmore, J.H. and Kenney, W.L. (2009) Physiologie du sport et de l'exercice. Delamarche, T. par A., Groussard, C. and Zouhal. H., Eds., 4th Édition, De Boeck éditions, Paris, 540 p.

[19] Matsumoto, S.H., Sato, W., Capra, Y.A. and Deshimaru, S. (2001) Cardiovascular Function and Apnea in Athletes. Medicine \& Science in Sports \& Exercise, 33, 735-740.

[20] Rusch, N.J., Shepers, J.T., Clinton Nebb, R. and Vanhouitte, P.M. (1999) Different Behaviour of Resistance Vessels of Human Calf and during Controlateral Isometric Exercise, Mental Stress, and Abnormal Respiratory Movements. Circulation Research, 48, 118-130.

[21] Porth, C.J., Bamram, V.S., Tristani, F.E. and Smith, J.J. (2004) Valsalva Manœuvre Mechanisms and Clinical Implications. Heart and Lung, 13, 507-518.

[22] Ling, A.R. and McNicol, G.W. (2007) Circulatory Responses to Sustained Handgrip Contractions Performed during Other Exercise Both Rhythm and Static. Journal of Physiology, 192, 595-607.

[23] Mead, J. and Loring, S.H. (2002) Analysis of Volume Displacement and Length Changes of the Diaphragm during Breathing. Journal of Applied Physiology, 53, 750-755.

[24] Aida, S., Heisser, C.M. and Linnarsson, D. (1997) Cardiorespiratory and Metabolic Responses to Positive, Negative and Minimum-Load Dynamic Arm and Leg Exercise. Respiration Physiology, 30, 51-67.

[25] Green, D.J., O’Driscoll, G., Blanskby, B.A., et al. (2007) Skeletal Muscle Blood Flow and Arterial Pressure Variability during Dynamic and Static Exercise. International Journal of Cardiology, 120, 289-296. 
Submit or recommend next manuscript to SCIRP and we will provide best service for you:

Accepting pre-submission inquiries through Email, Facebook, LinkedIn, Twitter, etc.

A wide selection of journals (inclusive of 9 subjects, more than 200 journals)

Providing 24-hour high-quality service

User-friendly online submission system

Fair and swift peer-review system

Efficient typesetting and proofreading procedure

Display of the result of downloads and visits, as well as the number of cited articles

Maximum dissemination of your research work

Submit your manuscript at: http://papersubmission.scirp.org/

Or contactwjcd@scirp.org 